http://ejournal.undip.ac.id/index.php/kapal

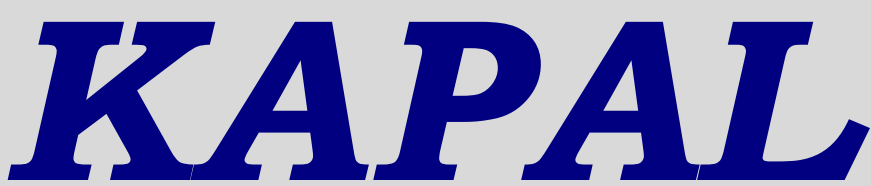

\title{
Studi Perancangan Floating Fuel Station Untuk Memenuhi Kebutuhan Bahan Bakar Masyarakat Nelayan Pesisir Di Kabupaten Demak
}

\author{
Sandy Nugraha ${ }^{l)}$, Eko Sasmito Hadi ${ }^{l)}$, Berlian Arswendo Adietya ${ }^{l)}$ \\ ${ }^{1)}$ Departemen Teknik Perkapalan, Fakultas Teknik, Universitas Diponegoro \\ Jl. Prof. Soedarto, SH, Kampus Undip Tembalang, Semarang, Indonesia 50275
}

diajukan pada : 27/05/18

direvisi pada : 30/06/18

diterima pada $: 13 / 07 / 18$

\begin{abstract}
Abstrak
Untuk mengatasi permasalahan pendistribusian BBM di pesisir Indonesia maka diperlukan solusi yaitu dengan membuat Floating Fuel Station yaitu pola pendistribusian bahan bakar nelayan dengan membuat SPBN dengan konsep terapung. Penyebab utama keterlambatan distribusi bahan bakar di Pantai Morodemak dikarenakan kondisi akses jalan yang sempit dan sering adanya rob air laut. Langkah awal dalam mendapatkan ukuran dimensi adalah dengan menyesuaikan jumlah kebutuhan BBM nelayan dalam satu bulan untuk menentukan besarnya muatan BBM yang dapat diangkut dan karakteristik perairan di Pantai Morodemak. Selanjutnya membuat enam macam model lambung, lambung terbaik dipilih berdasarkan equilibrium dan GZ stabilitas sementara yang ideal. Didapatkan ukuran utama lambung adalah LOA:30,0625m LWL:28,9690m LPP:28,2760m B:1,5m H:2,5m T:1,8m Displacement: 515,1Ton Cb:0,8737 LCB dari MS:-0,061. DWT:257,592Ton dan LWT:257,508Ton. Kapasitas tangki utama BBM nelayan Floating Fuel Station sebesar 270,3 $\mathrm{m}^{3}$ dan mampu membawa truk tangki dengan berat maksimal 18,216Ton. Dilakukan analisa untuk stabilitas, olah gerak dan analisa biaya operasional. Analisa stabilitas dan Seakeeping menggunakan Maxsurf sedangkan analisa biaya operasional menggunakan metode cost-benefit analysis. Dari analisa stabilitas didapatkan Floating Fuel Station memiliki stabilitas yang baik sesuai dengan kriteria dari IMO MSC.267(85) Part B Stability For Pontoons. Dari hasil analisa Seakeeping Floating Fuel Station mampu berlayar pada tinggi gelombang perairan laut jawa $2 \mathrm{~m}$ berdasarkan dari kriteria Tello,2009. Dari hasil analisa biaya operasional menggunakan costbenefit analysis Floating Fuel Station memiliki biaya operasional lebih rendah 28,49\% dibanding SPBN Morodemak Konvensional.
\end{abstract}

Copyright @ 2018, KAPAL, 1829-8370 (p), 2301-9069(e)

Kata Kunci : Floating Fuel Station, SPBN, Analisa Stabilitas, Seakeeping, cost-benefit analysis

\section{PENDAHULAN}

Sebagai negara maritim Indonesia memiliki luas laut mencapai 7,9 juta $\mathrm{km}^{2}$ dan juga memiliki 17.508 pulau.[1] Indonesia memiliki lautan yang sangat luas dan memiliki potensi sumber daya maritim yang berada di laut berupa ikan, kerang, minyak bumi dan biota laut lainnya. Indonesia juga masih memiliki banyak permasalahan sosial dan juga pemerataan ekonomi untuk masyarakat

*) Penulis Korespondensi :

Email : bigsandysn@gmail.com pesisir yang tersebar di seluruh Indonesia.

Indonesia memiliki 112 terminal BBM [2] atau depot yang melayani pengisian BBM dari Pertamina ke agen penyalur yang selanjutnya disalurkan melalui SPBU (Stasiun pengisian bahan bakar umum), APMS (Agen premium dan minyak solar), SPBN (Stasiun Pengisian Bahan Bakar Nelayan), dan SPBB (Stasiun pengisian bahan bakar untuk Bunker) atau ke industri dan kapal yang diperkirakan sebanyak 13.000 perusahaan.[3] 
Permasalahan utama untuk memenuhi kebutuhan kapal-kapal nelayan di Pesisir Morodemak adalah pendistribusian bahan bakar yang masih kurang[4], hal ini dikarenakan pendistribusian bahan bakar untuk bagian Morodemak masih banyak mengalami kendala diantaranya banyak daerah daerah pesisir di Indonesia yang memiliki akses jalan yang susah dilalui mobil besar yang mengangkut bahan bakar dan adanya rob air laut yang menutupi akses jalan di Pantai Morodemak.

Untuk mengatasi permasalahan pendistribusian bahan bakar di pesisir Indonesia maka diperlukan solusi yaitu dengan membuat Floating Fuel Station Yaitu pola pendistribusian bahan bakar nelayan dengan membuat SPBN (Stasiun pengisian bahan bakar nelayan) dengan konsep terapung dimana bahan bakar dibawa dari pelabuhan di pulau besar dan langsung didistribusikan ke kapal nelayan yang berada di pesisir dengan mengoptimalkan waktu pengiriman dan sasaran pengiriman yang tepat melalui jalur laut, tugas akhir ini mengambil kasus di wilayah pesisir Kabupaten Demak. Belum ada studi terdahulu tentang permasalahan ini di kabupaten Demak.

Tujuan dalam penelitian ini adalah untuk mendapatkan ukuran utama, rencana garis, rencana umum, analisa stabilitas, analisa olah gerak, dan analisa biaya operasional Floating Fuel Station yang sesuai dalam pendistribusian bahan bakar untuk masyarakat Pesisir di Indonesia. Dan juga mengetahui perbandingan Floating Fuel Station yang memiliki sistem propulsi dengan yang tidak memiliki sistem propulsi.

Manfaat dari penelitian tugas akhir ini yaitu pertama, memberikan solusi kepada pemerintah sebagai pemecahan masalah dalam pendistribusian bahan bakar untuk masyarakat pesisir di Indonesia yang lebih fungsional, efektif, dan efisien. Kedua, menciptakan kesejahteraan masyarakat pesisir di Indonesia. Ketiga, sebagai sarana untuk meningkatkan inovasi teknologi di Indonesia.

\section{METODE}

Dalam penelitian ini objek penelitian adalah merancang Floating Fuel Station yaitu kapal yang memiliki fungsi seperti SPBN (Stasiun Pengisian Bahan Bakar Nelayan) yang mampu mengangkut dan mendistribusikan langsung BBM kepada nelayan di Pantai Morodemak, Kabupaten Demak. Data penelitian diperoleh dari Dinas kelautan dan perikanan kabupaten Demak, PPP Morodemak, PT. Anwusa Demak, PT. Pertamina Persero, PT.
AKR Corporindo dan masyarakat nelayan di Pantai Morodemak, Kabupaten Demak.

Dalam menentukan ukuran utama Floating Fuel Station menggunakan Metode Spiral [5] dimana dalam metode ini didapatkan ukuran utama sesuai dari aspek kebutuhan yang direncanakan dan dibutuhkan seperti ukuran tanki utama BBM, Freshwater Tank, perhitungan dasar lambung ganda, perhitungan Double Hull, perhitungan ruang kamar mesin dan karakteristik perairan. Lambung Floating Fuel Station dibuat dalam enam variasi model, variasi model berupa variasi bentuk lambung, variasi bentuk main deck, dan variasi $\mathrm{Cb}$.

Model variasi lambung Floating Fuel Station akan di analisa sementara equilibrium dan stabilitasnya terlebih dahulu untuk menentukan model lambung ideal yang akan digunakan. Setelah mendapatkan bentuk lambung ideal lalu akan dibuat rencana umum dan langsung melakukan analisa stabilitas, Seakeeping serta analisa biaya operasional terhadap Floating Fuel Station. Pembuatan variasi model lambung, analisa stabilitas dan Seakeeping menggunakan bantuan Software Maxsurf. Analisa biaya operasional menggunakan metode Cost-benefit Analysis.

\subsection{Flow Chart Penelitian}

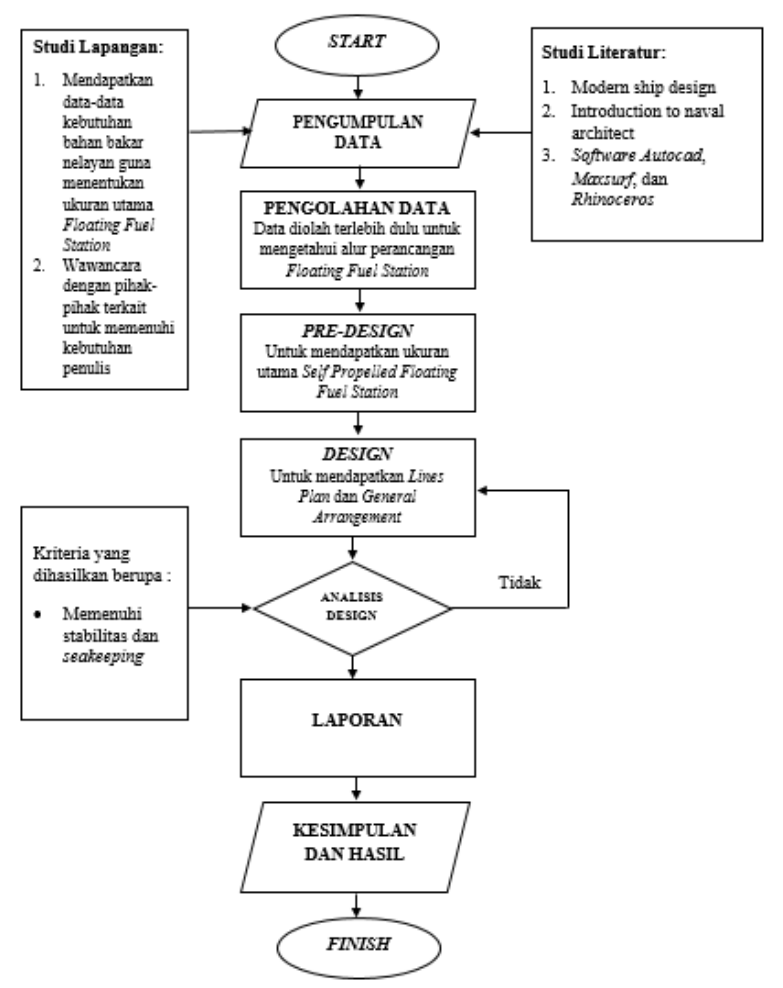

Gambar 1. Flow Chart Penelitian

Gambar 1 menjelaskan Flow Chart penelitian dimana data diambil dari dinas dan lembaga terkait yang langsung terkait dengan 
pendistribusian bahan bakar di Pantai Morodemak dan selanjutnya diolah lalu didapatkan ukuran utama untuk selanjutnya membuat design yang diharapkan. Lalu di analisa stabilitas, seakeeping, dan Cost-benefit analysis.

\section{HASIL DAN PEMBAHASAN}

\subsection{Penentuan Ukuran Utama}

Berdasarkan jumlah kebutuhan BBM nelayan yang di dapat dari Dinas Kelautan Dan perikanam Kabupaten Demak dalam satu bulan nelayan Pantai Morodemak membutuhkan \pm 2.000 .000 L.[6] Dalam skema pengiriman Floating Fuel Station dalam satu minggu terdapat dua kali pengiriman sehingga Floating Fuel Station harus mampu membawa BBM \pm 250.000 $\mathrm{L}$ dalam satu kali pengiriman. Setelah didapatkan ukuran utama tangki muatan. Lalu ditambahkan Double Hull dan Double Bottom sesuai SOLAS. Selanjutnya melakukan estimasi ukuran panjang kamar mesin melalui kapal pembanding yaitu LCT yang memiliki bentuk lambung yang sama yaitu barge. Setelah melakukan beberapa perhitungan estimasi lalu didapatkan ukuran utama sementara berdasarkan estimasi yaitu:

$\begin{array}{ll}\mathrm{LPP} & =27 \text { meter } \\ \mathrm{B} & =11,52 \text { meter } \\ \mathrm{H} & =2,5 \text { meter } \\ \mathrm{T} & =1,8 \text { meter } \\ \mathrm{Cb} & =0,80-0,95 \\ \mathrm{Vs} & =10 \quad \text { knot }\end{array}$

\subsection{Pembuatan Variasi Model Lambung}

Setelah mendapatkan ukuran utama dari hasil estimasi langkah selanjutnya membuat enam variasi model lambung, variasi model berupa variasi bentuk lambung dan variasi bentuk main deck. Pembuatan model ini menggunakan Software Rhinoceros dan Maxsurf Modeler.

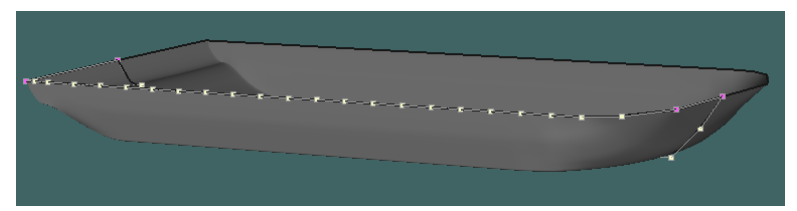

Gambar 2. Model 1

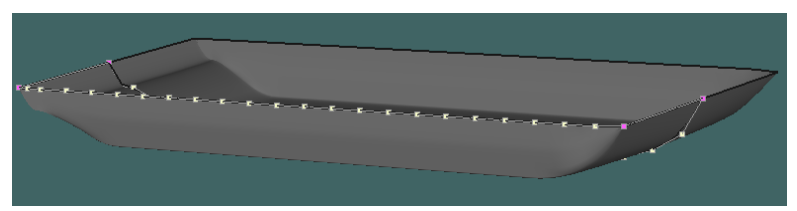

Gambar 3. Model 2

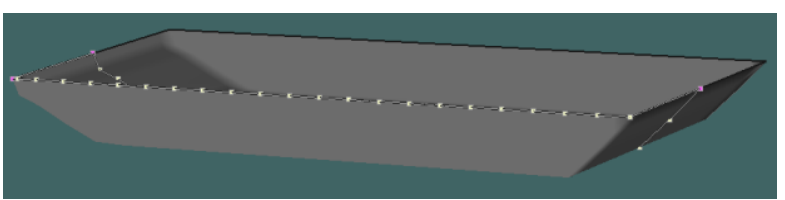

Gambar 4. Model 3

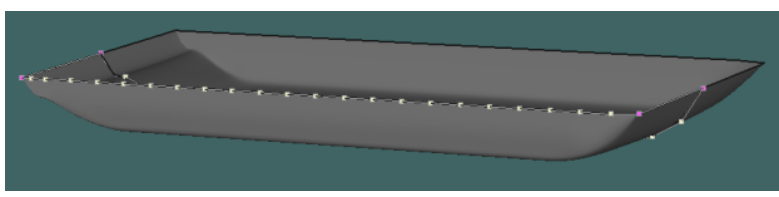

Gambar 5. Model 4

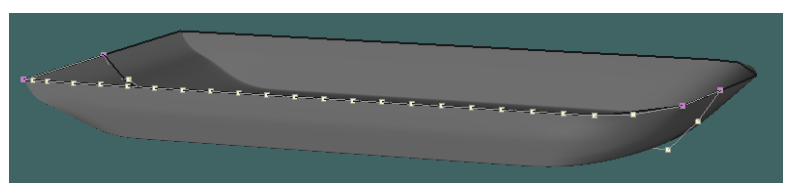

Gambar 6. Model 5

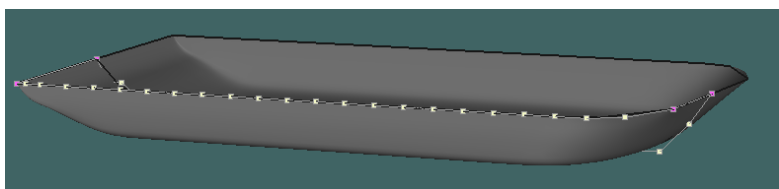

Gambar 7. Model 6

Gambar 2 - 7 menampilkan bentuk variasi lambung yang sudah di desain. Bentuk variasi pada lambung yaitu berupa variasi lambung yang berbentuk round dan square, serta bentuk variasi main deck yang berbentuk round dan square. Dan juga terdapat kombinasi antara bentuk keduanya.

\subsection{Pemilihan Model Lambung}

Pemilihan model lambung ideal dengan cara menganalisa sementara equilibrium dan stabilitasnya dengan memasukkan tangki utama saja sesuai volume tangki yang sudah direncanakan. Model yang paling ideal adalah dengan melihat titik trim equilibrium dan titik GZ stabilitas dari setiap model.

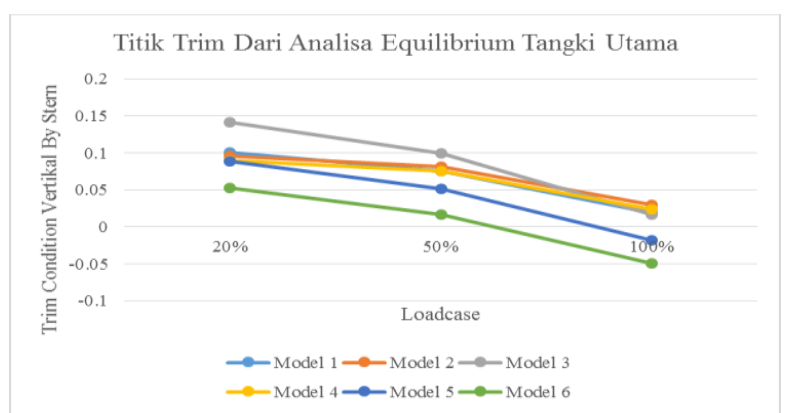

Gambar 8. Grafik Titik Equilibrium Setiap Model

Gambar 8 menunjukkan hasil dari analisa equilibrium sementara berupa titik trim pada keenam model Floating Fuel Station yang terdapat pada setiap kondisi 


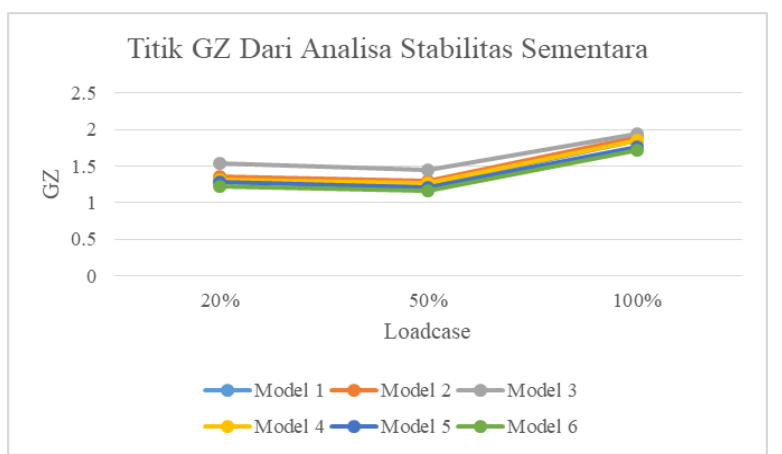

Gambar 9. Grafik Titik GZ Stabilitas Setiap Model

Gambar 9 menunjukkan hasil dari analisa stabilitas sementara pada keenam model Floating Fuel Station berupa titik GZ.

Model lambung yang dipilih paling ideal dari hasil analisa sementara equilibrium dan stabilitas adalah lambung model 2. Model 2 dipilih karena memiliki lambung dengan stabilitas yang baik diurutan kedua dengan nilai titik GZ paling tinggi 1,896 di kondisi $100 \%$ dan titik trim equilibrium besar hanya pada satu titik saat kondisi $100 \%$, walaupun model 3 menempati urutan pertama dengan titik GZ tertinggi 1,935 di kondisi $100 \%$ tetapi, model 3 memiliki nilai trim equilibrium paling besar di dua kondisi $20 \%$ dan $50 \%$.

\subsection{Lines Plan}

Rencana garis Lines Plan model lambung 2 yang dipilih dari hasil analisa sebelumnya. Rencana garis pada gambar 10 diambil dari Software Maxsurf Modeller kemudian di export ke dalam Software Autocad.

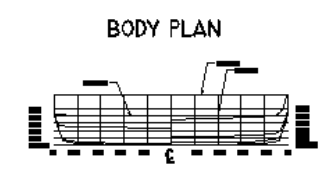

SHEER PLAN

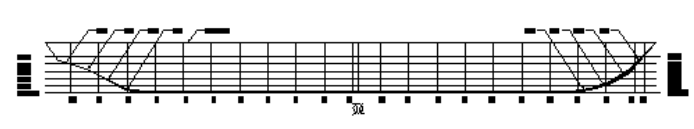

HALF BREADTH PLAN

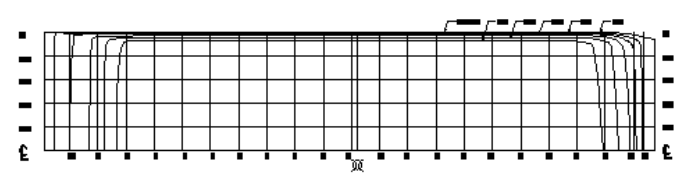

Gambar 10. Lines Plan Floating Fuel Station

$\begin{array}{lll}\mathrm{H} & =2,5 & \mathrm{~m} \\ \mathrm{~T} & =1,8 & \mathrm{~m} \\ \text { Volume } & =502,520 & \mathrm{~m}^{3} \\ \text { Displacement } & =515,1 & \mathrm{~T} \\ \mathrm{Cb} & =0,837 & \\ \mathrm{Cp} & =0,889 & \\ \mathrm{Cm} & =0,941 & \\ \mathrm{Vs} & =10 & \text { Knot }\end{array}$

LCB from MS = -0,061

\subsection{Rencana Umum}

Rencana umum didefinisikan sebagai perencanaan ruangan yang dibutuhkan sesuai dengan fungsi dan perlengkapannya.[7] Crew kapal berjumlah 4 orang. Floating Fuel Station dirancang untuk dapat memenuhi kebutuhan BBM Nelayan Pesisir, dilengkapi dengan 4 Fuel Dispenser dengan kapasitas tangki utama sebesar $270.300 \mathrm{~L}$ untuk dapat melayani pembelian BBM oleh nelayan dan juga dirancang untuk dapat mengangkut satu truk tangki dengan berat maksimal 18,216 Ton. DWT: 257,592 Ton dan LWT: 257,508 Ton. Total HP sebesar : 255,5 HP dan total hambatan: 29,6 kN. Floating Fuel Station memiliki kriteria yang sesuai dengan kondisi perairan laut utara jawa yang termasuk moderate sea dengan tinggi gelombang 1-2 $\mathrm{m}$ [8] dan mempunyai sarat yang disesuaikan dengan kedalaman alur dermaga PPP Morodemak.

Hasil dari rencana umum Floating Fuel Station dapat dilihat pada gambar 11.
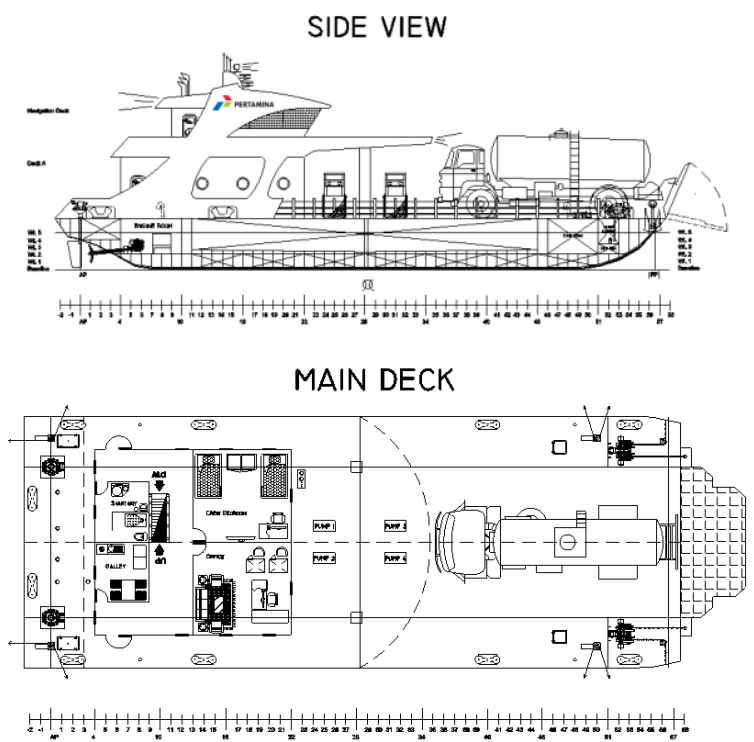

Dengan ukuran utama sebagai berikut:

\begin{tabular}{|c|c|}
\hline LOA & $=30,0625$ \\
\hline LWL & $=28,9690$ \\
\hline LPP & $=28,2760$ \\
\hline B & $=11,5$ \\
\hline
\end{tabular}


MAIN TANK

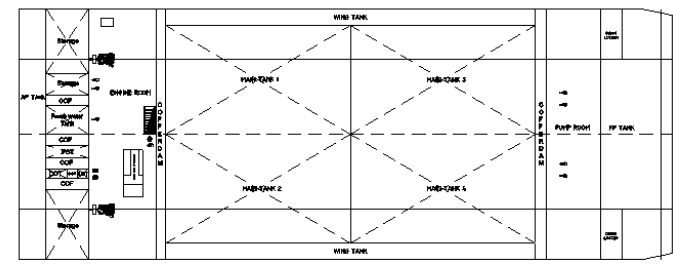

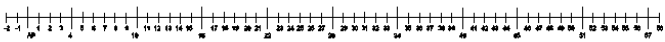

DOUBLE BOTTOM
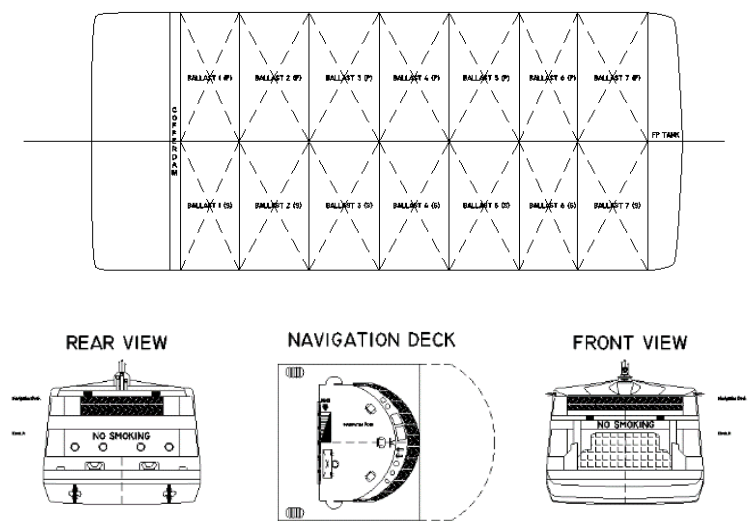

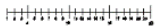

Gambar 11. Rencana Umum Floating Fuel Station

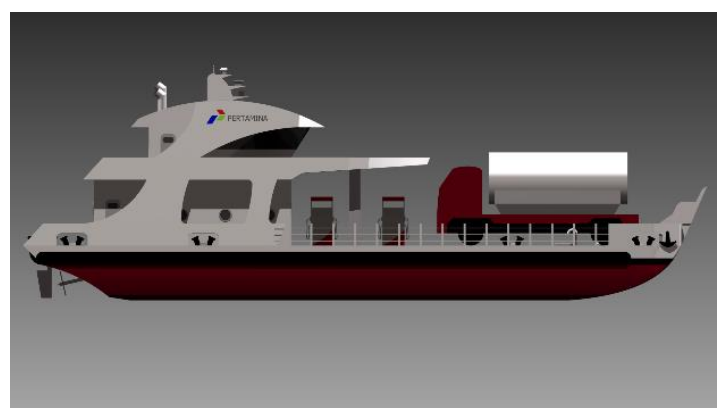

Gambar 12. Model 3D Tampak Samping

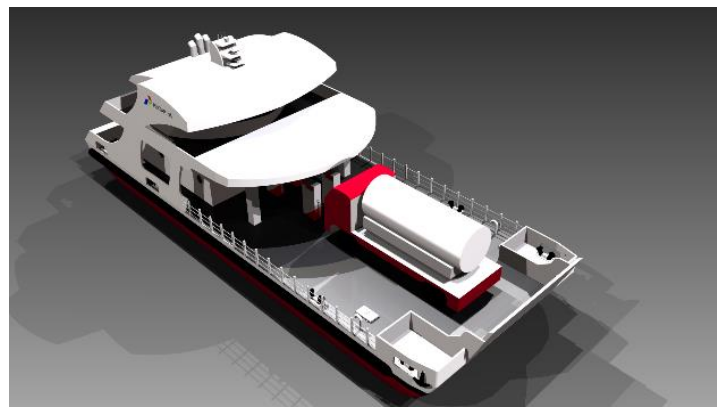

Gambar 13. Model 3D Tampak Atas

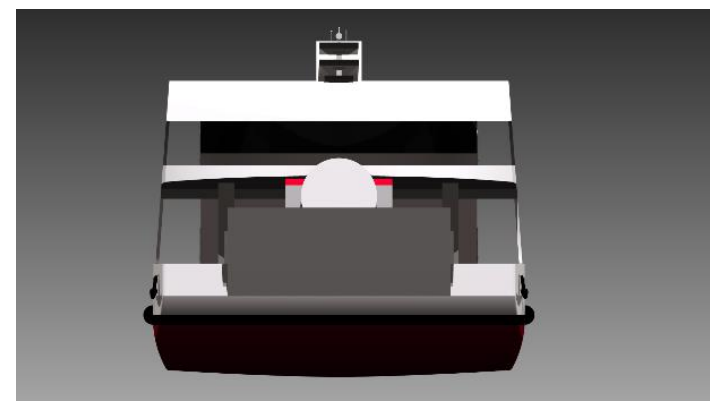

Gambar 14. Model 3D Tampak Depan

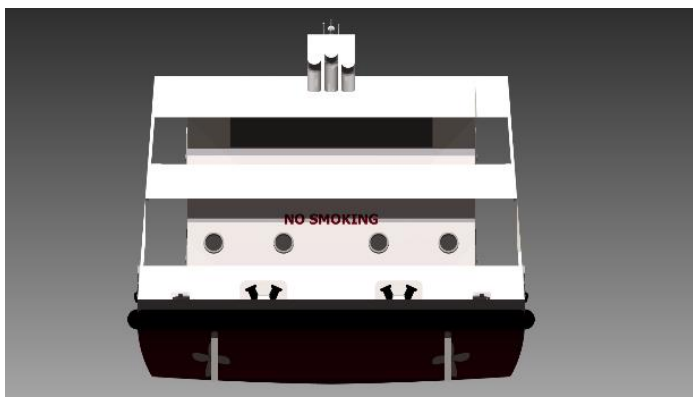

Gambar 15. Model 3D Tampak Belakang

Gambar 12 - 15 menampilkan bentuk permodelan 3D dari Floating Fuel Station dari beberapa sisi. Permodelan 3D mengunakan Software Autodesk dan Rhinoceros.

\subsection{Analisis Stabilitas}

Setelah semua komponen utama sudah siap dan sudah dimasukkan semua ke dalam software Maxsurf Stability, langkah selanjutnya adalah melakukan analisa stabilitas untuk setiap kondisi yang sudah ditentukan pada seksi sebelumnya dan analisa stabilitas menggunakan kriteria dari IMO MSC.267(85) Code on intacts stability Part B For Pontoons.[9]

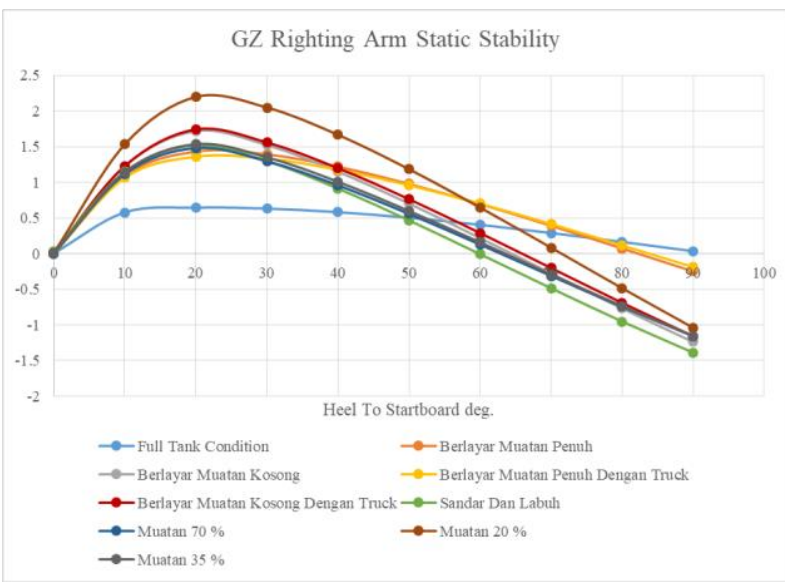

Gambar 16. Grafik Stabilitas Statis

Gambar 16 menunjukan grafik dari hasil analisa stabilias statis setiap model. Terdapat sembilan grafik stabilitas yang menggambarkan keadaan di setiap kondisi. 


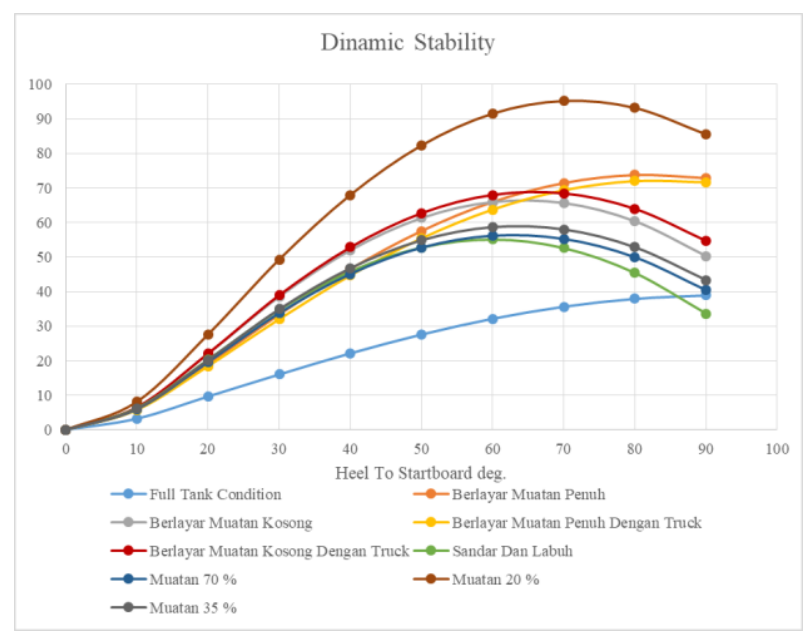

Gambar 17. Grafik Stabilitas Dinamis

Gambar 17 menunjukan grafik dari hasil analisa stabilias statis setiap model. Terdapat sembilan grafik stabilitas yang menggambarkan keadaan di setiap kondisi.

Tabel 1. Kriteria Full Tank Condition

\begin{tabular}{clcc}
\hline Code & \multicolumn{1}{c}{ Criteria } & Actual & Status \\
\hline 2.2 Pontoons & 2.2.4.1 GZ Area: To Max GZ & 7.2767 & Pass \\
2.2 Pontoons & 2.2.4.2 Angle Of Equilibrium Ratio & -3.65 & Pass \\
2.2 Pontoons & 2.2.4.3 Angle Of Vanishing Stability $<=100 \mathrm{~m}$ & 90.0 & Pass \\
2.2 Pontoons & 2.2.4.3 Angle Of Vanishing Stability $=>150 \mathrm{~m}$ & 90.0 & Pass \\
\hline
\end{tabular}

Tabel 2. Kriteria Berlayar Muatan Penuh

\begin{tabular}{clcl}
\hline Code & \multicolumn{1}{c}{ Criteria } & Actual & Status \\
\hline 2.2 Pontoons & 2.2 .4 .1 GZ Area: To Max GZ & 23.0158 & Pass \\
2.2 Pontoons & 2.2 .4 .2 Angle Of Equilbrium Ratio & -0.25 & Pass \\
2.2 Pontoons & 2.2 .4 .3 Angle Of Vanishing Stability $<=100 \mathrm{~m}$ & 82.2 & Pass \\
2.2 Pontoons & 2.2 .4 .3 Angle Of Vanishing Stability $=>150 \mathrm{~m}$ & 82.2 & Pass \\
\hline
\end{tabular}

Tabel 3. Kriteria Berlayar Muatan Kosong

\begin{tabular}{clcc}
\hline Code & \multicolumn{1}{c}{ Criteria } & Actual & Status \\
\hline 2.2 Pontoons & 2.2.4.1 GZ Area: To Max GZ & 23.5379 & Pass \\
2.2 Pontoons & 2.2.4.2 Angle Of Equilibrium Ratio & -0.38 & Pass \\
2.2 Pontoons & 2.2 .4 .3 Angle Of Vanishing Stability $<=100 \mathrm{~m}$ & 64.4 & Pass \\
2.2 Pontoons & 2.2 .4 .3 Angle Of Vanishing Stability $=>150 \mathrm{~m}$ & 64.4 & Pass \\
\hline
\end{tabular}

Tabel 4. Kriteria Berlayar Muatan Penuh Dengan Truck

\begin{tabular}{|c|c|c|c|}
\hline Code & Criteria & Actual & Status \\
\hline 2.2 Pontoons & 2.2.4.1 GZ Area: To Max GZ & 22.1664 & Pass \\
\hline 2.2 Pontoons & 2.2.4.2 Angle Of Equilibrium Ratio & -0.21 & Pass \\
\hline 2.2 Pontoons & 2.2.4.3 Angle Of Vanishing Stability $<=100 \mathrm{~m}$ & 83.8 & Pass \\
\hline 2.2 Pontoons & 2.2.4.3 Angle Of Vanishing Stability $\Rightarrow 150 \mathrm{~m}$ & 83.8 & Pass \\
\hline
\end{tabular}

Tabel 5. Kriteria Berlayar Muatan Kosong Dengan Truck

\begin{tabular}{clcc}
\hline Code & \multicolumn{1}{c}{ Criteria } & Actual & Status \\
\hline 2.2 Pontoons & 2.2.4.1 GZ Area: To Max GZ & 23.6725 & Pass \\
2.2 Pontoons & 2.2.4.2 Angle Of Equilibrium Ratio & -0.32 & Pass \\
2.2 Pontoons & 2.2.4.3 Angle Of Vanishing Stability $\measuredangle=100 \mathrm{~m}$ & 65.9 & Pass \\
2.2 Pontoons & 2.2.4.3 Angle Of Vanishing Stability $\Rightarrow 150 \mathrm{~m}$ & 65.9 & Pass \\
\hline
\end{tabular}

Tabel 6. Kriteria Sandar Dan Labuh

\begin{tabular}{clcc}
\hline Code & \multicolumn{1}{c}{ Criteria } & Actual & Status \\
\hline 2.2 Pontoons & 2.2.4.1 GZ Area: To Max GZ & 20.3171 & Pass \\
2.2 Pontoons & 2.2.4.2 Angle Of Equilibrium Ratio & -3.41 & Pass \\
2.2 Pontoons & 2.2 .4 .3 Angle Of Vanishing Stability $<=100 \mathrm{~m}$ & 59.9 & Pass \\
2.2 Pontoons & 2.2 .4 .3 Angle Of Vanishing Stability $\Rightarrow>150 \mathrm{~m}$ & 59.9 & Pass \\
\hline
\end{tabular}

Tabel 7. Kriteria Muatan $70 \%$

\begin{tabular}{clcl}
\hline Code & \multicolumn{1}{c}{ Criteria } & Actual & Status \\
\hline 2.2 Pontoons & 2.2.4.1 GZ Area: To Max GZ & 19.6126 & Pass \\
2.2 Pontoons & 2.2.4.2 Angle Of Equilibrium Ratio & -0.05 & Pass \\
2.2 Pontoons & 2.2.4.3 Angle Of Vanishing Stability $<=100 \mathrm{~m}$ & 62.9 & Pass \\
2.2 Pontoons & 2.2.4.3 Angle Of Vanishing Stability $\Rightarrow>150 \mathrm{~m}$ & 62.9 & Pass \\
\hline
\end{tabular}

Tabel 8. Kriteria Muatan $20 \%$

\begin{tabular}{clcl}
\hline Code & \multicolumn{1}{c}{ Criteria } & Actual & Status \\
\hline 2.2 Pontoons & 2.2.4.1 GZ Area: To Max GZ & 31.6413 & Pass \\
2.2 Pontoons & 2.2.4.2 Angle Of Equilibrium Ratio & -0.43 & Pass \\
2.2 Pontoons & 2.2.4.3 Angle Of Vanishing Stability <= $100 \mathrm{~m}$ & 71.5 & Pass \\
2.2 Pontoons & 2.2.4.3 Angle Of Vanishing Stability => $150 \mathrm{~m}$ & 71.5 & Pass \\
\hline
\end{tabular}

Tabel 9. Kriteria Muatan $65 \%$

\begin{tabular}{clcl}
\hline Code & \multicolumn{1}{c}{ Criteria } & Actual & Status \\
\hline 2.2 Pontoons & 2.2.4.1 GZ Area: To Max GZ & 21.5855 & Pass \\
2.2 Pontoons & 2.2.4.2 Angle Of Equilibrium Ratio & -0.29 & Pass \\
2.2 Pontoons & 2.2.4.3 Angle Of Vanishing Stability $<=100 \mathrm{~m}$ & 63.5 & Pass \\
2.2 Pontoons & 2.2.4.3 Angle Of Vanishing Stability $\Rightarrow 150 \mathrm{~m}$ & 63.5 & Pass \\
\hline
\end{tabular}

Hasil analisa stabilitas berdasarkan kriteria IMO yang bisa dilihat pada tabel 1 - 9 menunjukkan bahwa semua hasil analisa stabilitas Floating Fuel Station di setiap kondisi memenuhi kriteria yang ditentukan dalam IMO MSC.267(85) Code on intacts stability Part B For Pontoons.

\subsection{Analisis Olah Gerak}

Analisa olah gerak kapal[10] Floating Fuel Station menggunakan bantuan dari software Maxsurf Motion dengan menganalisa olah gerak Floating Fuel Station berdasarkan dari sudut maksimum pada roll dan pitch yang ditentukan dalam kriteria "General Operability Limiting Criteria For Ship, Tello 2009" yang mengatur standar penerimaan olah gerak untuk Floating Fuel Station. Kriteria Tello 2009.[11] Analisa olah gerak ini dilakukan untuk sudut $90^{\circ}$ (Beam), $135^{\circ}$ (Bow Quartering), dan $180^{\circ}$ (Head) dengan kecepatan kapal 10 knots dan tinggi gelombang setinggi $0.5 \mathrm{~m}, 1 \mathrm{~m}$, dan $2 \mathrm{~m}$ sesuai dengan kondisi di laut jawa dan kondisi laut ekstrim dengan gelombang $4 \mathrm{~m}$. 
Tabel 10. Kriteria Penerimaan Tello 2009

\begin{tabular}{ll}
\hline \multicolumn{1}{c}{ Criteria } & Prescribed Value \\
\hline Green Water Deck & $5 \%$ (prob) \\
Slamming & $3 \%$ (prob) \\
Propeller emergence & $15 \%$ (prob) \\
VA at Bridge & $0,2 \mathrm{~g}(\mathrm{rms})$ \\
LA at Bridge & $0,1 \mathrm{~g}(\mathrm{rms})$ \\
VA at work, deck & $0,2 \mathrm{~g}(\mathrm{rms})$ \\
LA at work, deck & $0,1 \mathrm{~g}(\mathrm{rms})$ \\
Roll & $6 \mathrm{deg}$ \\
Pitch & $3 \mathrm{deg}$ \\
\hline
\end{tabular}

a. Hasil Perhitungan RAO

Respon gerakan kapal terhadap gelombang regular dinyatakan dalam RAO (Response Amplitudo Operator), dimana RAO adalah rasio antara amplitudo gerakan kapal (baik translasi maupun rotasi) terhadap amplitudo gelombang pada frekuensi tertentu.

Pada kenyataannya, gelombang di laut adalah gelombang acak sehingga respon kapal terhadap gelombang regular yang dinyatakan dalam RAO tidak dapat menggambarkan respon kapal pada keadaan sesungguhnya di laut.[12]

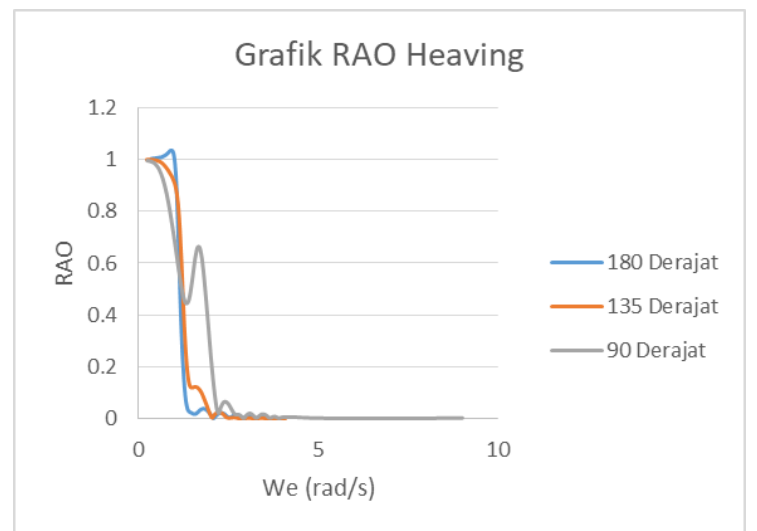

Gambar 18. Grafik RAO Heaving

Gambar 18 menunjukkan RAO heaving di gelombang reguler. Puncak RAO tertinggi terlihat saat terjadi heave di sudut $180^{\circ}$ (Head). Terlihat bahwa pada sudut $90^{\circ}$ (Beam) setelah terjadi penurunan pada kurva terlihat kurva mengalami puncak kenaikan lagi sebesar 0,631 RAO pada frekuensi $1,744 \mathrm{rad} / \mathrm{s}$.

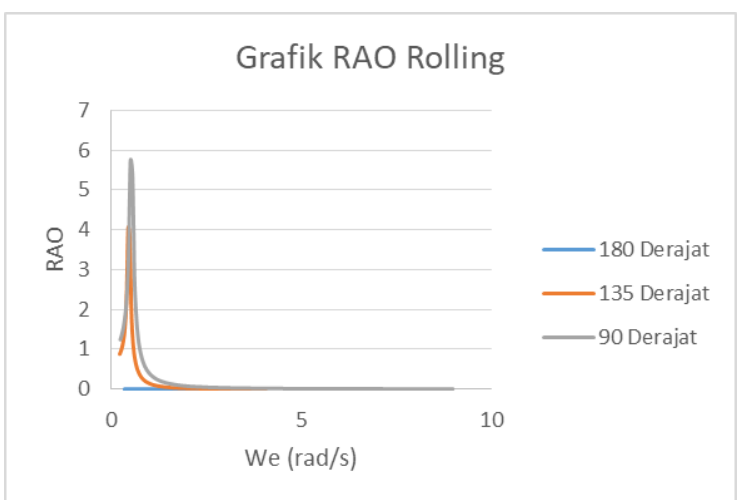

Gambar 19. Grafik RAO Rolling

Gambar 19 menunjukkan RAO rolling di gelombang reguler. Bentuk kurva RAO dari tiap sudut sudut $90^{\circ}$ (Beam) , 135 (Bow Quartering), dan $180^{\circ}$ (Head) tampak sama. Dimana untuk sudut $135^{\circ}$ (Bow Quartering) memberikan gerakan respon rolling yang lebih rendah pada frekuensi dimana puncak kurva terlewati.

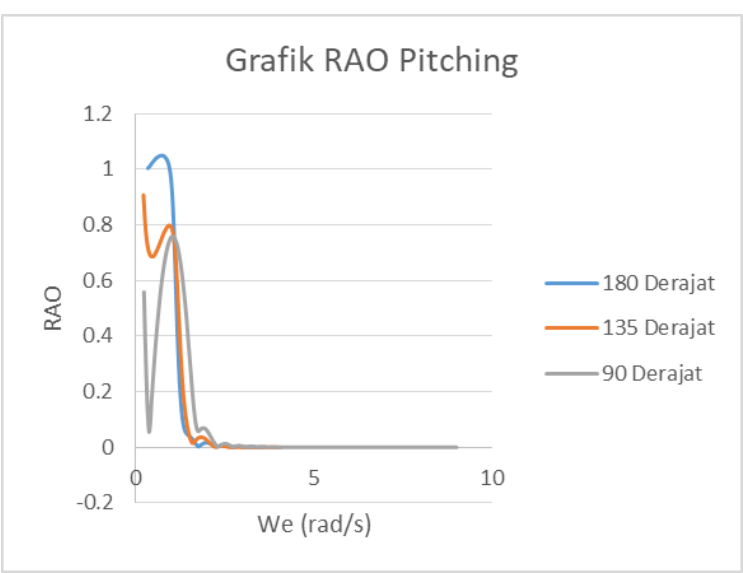

Gambar 20. Grafik RAO Pitching

Gambar 20 menunjukkan RAO gerakan pitching. Terlihat pada kurva bahwa untuk sudut $90^{\circ}$ (Beam) dan $135^{\circ}$ (Bow Quartering) terdapat kenaikan puncak kurva RAO dimana puncak RAO kedua tertinggi terdapat pada sudut $90^{\circ}$ (Beam) dengan nilai 0,735 RAO pada frekuensi $1,153 \mathrm{rad} / \mathrm{s}$. Sedangkan pada sudut $180^{\circ}$ (Head) hanya memiliki satu puncak RAO tertinggi.

b. Spektrum Gelombang JONSWAP

Kondisi gelombang di laut yang sebenarnya digambarkan dalam bentuk spektrum gelombang. Kecepatan kapal dan arah sudut datang gelombang berpengaruh terhadap spektrum gelombang yang dihasilkan atau yang disebut spektrum gelombang papasan.[12] 


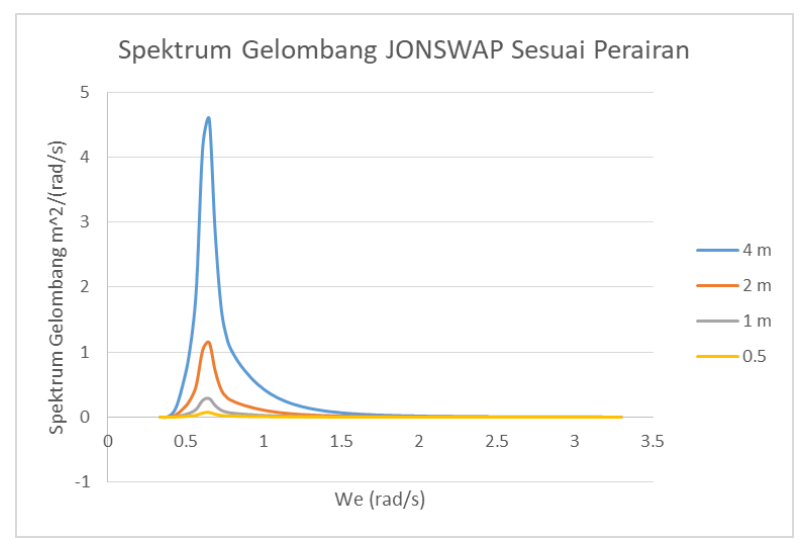

Gambar 21. Grafik Spektrum Gelombang JONSWAP

Gambar 21 menunjukkan bahwa puncak spektrum tertinggi terdapat pada gelombang $4 \mathrm{~m}$, sedangkan kurva spektrum terendah terdapat pada gelombang $0,5 \mathrm{~m}$.

c. Hasil Perhitungan RMS

Tabel 11. RMS Heaving, Rolling Dan Pitching Gelombang 0,5 m

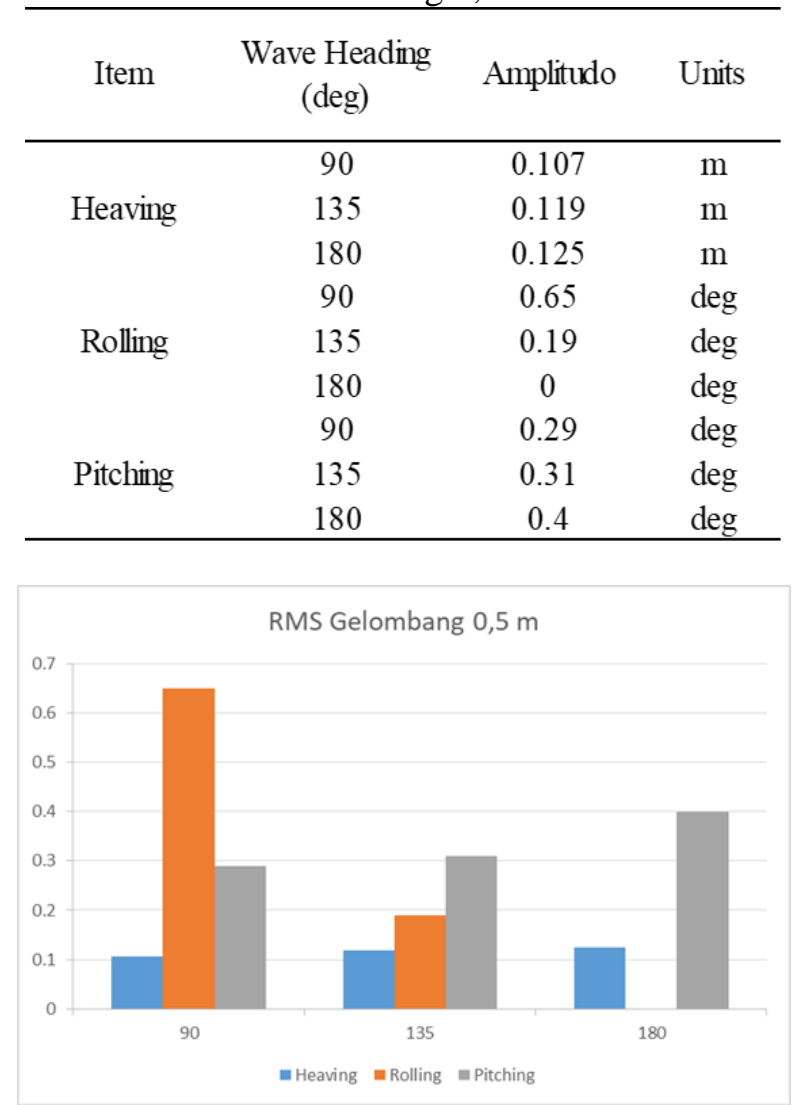

Gambar 22. RMS Heaving, Rolling Dan Pitching Gelombang 0,5 m
Tabel 12. RMS Heaving, Rolling Dan Pitching Gelombang $1 \mathrm{~m}$

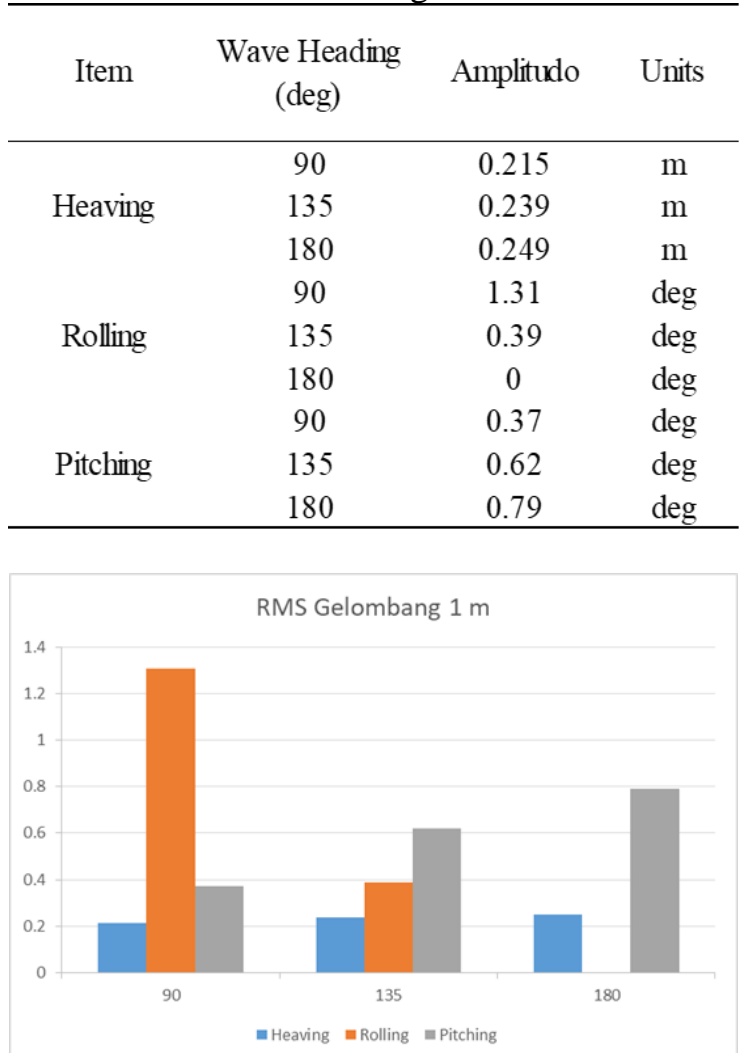

Gambar 23. Grafik RMS Heaving, Rolling Dan Pitching Gelombang $1 \mathrm{~m}$

Tabel 13. RMS Heaving, Rolling Dan Pitching Gelombang $2 \mathrm{~m}$

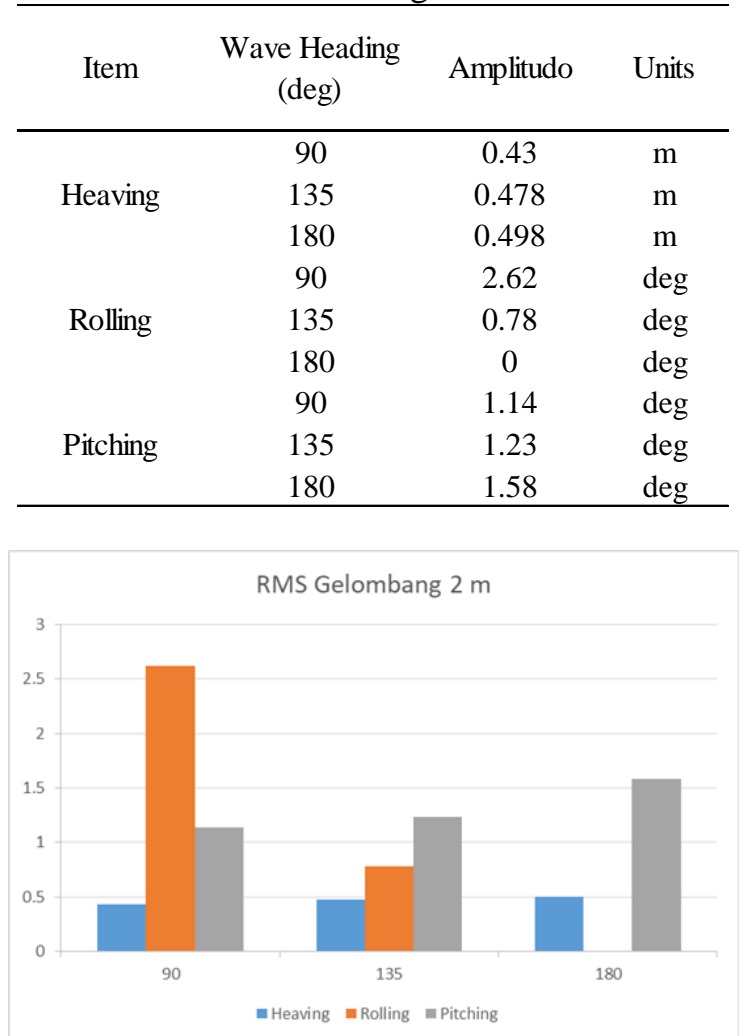

Gambar 24. Grafik RMS Heaving, Rolling Dan Pitching Gelombang $2 \mathrm{~m}$ 
Tabel 14. RMS Heaving, Rolling Dan Pitching Gelombang $4 \mathrm{~m}$

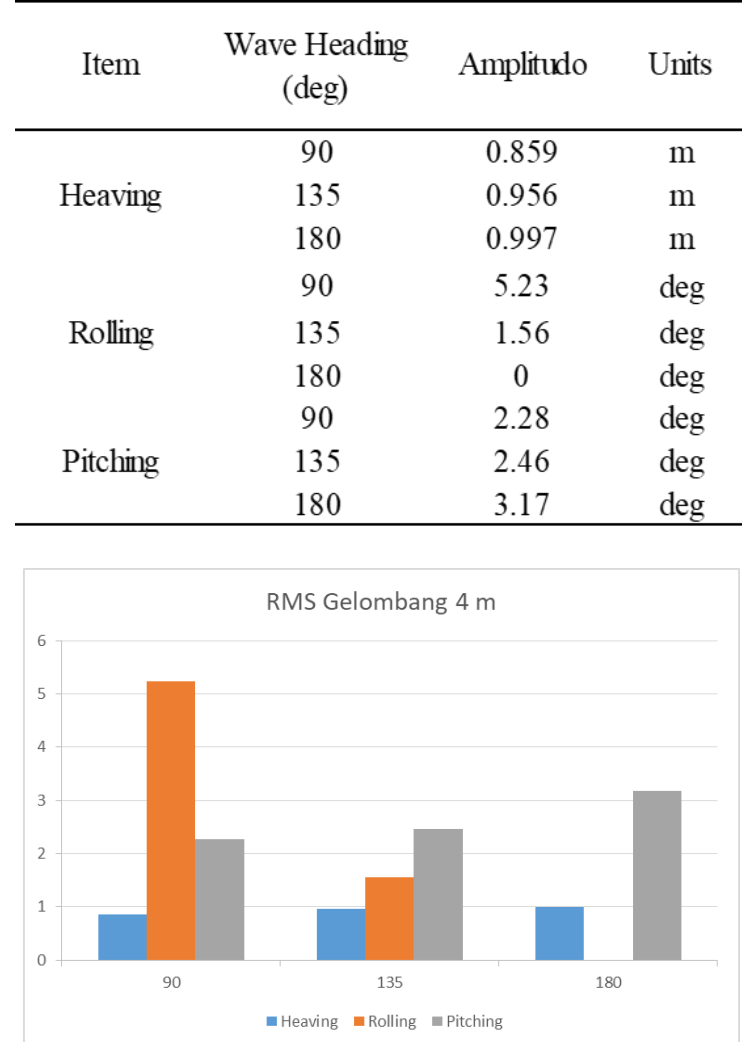

Gambar 25. Grafik RMS Heaving, Rolling Dan Pitching Gelombang $4 \mathrm{~m}$

Berdasarkan kriteria yang ditetapkan oleh (Tello, 2009) [11] untuk sudut maksimum roll adalah 6 derajat dan sudut maksimum untuk pitch adalah 3 derajat.

Pada tabel 11 tinggi gelombang $0,5 \mathrm{~m}$ Floating Fuel Station memenuhi kriteria yang ditetapkan oleh Tello 2009. Dengan nilai Rolling tertinggi 0,65 deg pada sudut $90^{\circ}$ dan nilai Pitching Tertinggi 0,4 deg pada sudut $180^{\circ}$.

Pada tabel 12 tinggi gelombang $1 \mathrm{~m}$ Floating Fuel Station memenuhi kriteria yang ditetapkan oleh Tello 2009. Dengan nilai Rolling tertinggi 1,31 deg pada sudut $90^{\circ}$ dan nilai Pitching Tertinggi 0,79 deg pada sudut $180^{\circ}$.

Pada tabel 13 tinggi gelombang $2 \mathrm{~m}$ Floating Fuel Station memenuhi kriteria yang ditetapkan oleh Tello 2009. Dengan nilai Rolling tertinggi 2,62 deg pada sudut $90^{\circ}$ dan nilai Pitching Tertinggi 1,58 deg pada sudut $180^{\circ}$.

Pada tabel 14 tinggi gelombang ekstrim $4 \mathrm{~m}$ Floating Fuel Station, Rolling memenuhi kriteria yang ditetapkan oleh Tello 2009 [11] sedangkan Pitching tidak memenuhi kriteria yang ditetapkan Tello 2009. Dengan nilai Rolling tertinggi 5,23 deg pada sudut $90^{\circ}$ dan nilai Pitching Tertinggi 3,2 deg pada sudut $180^{\circ}$.
Jadi untuk standar laut normal perairan Pantai Utara Jawa dengan gelombang maksimal 2 $\mathrm{m}$, Floating Fuel Station memenuhi kriteria olah gerak yang ditentukan oleh Tello 2009.

\subsection{Analisis Biaya Operasional}

Analisa biaya[13] dilakukan dengan menggunakan metode cost-benefit analysis yaitu dengan mengkomparasi jumlah kebutuhan biaya operasional Floating Fuel Station dengan SPBN Morodemak (Konvensional) agar dapat diketahui perbandingan besarnya biaya operasional antara Floating Fuel Station dengan SPBN Morodemak.[14]

Tabel 14.Biaya Operasional Floating Fuel Station

\begin{tabular}{lrrrr}
\hline \multicolumn{1}{c}{ Nama } & Jumlah & Estimasi Biaya (Rp) & \multicolumn{1}{c}{ Total (Rp) } \\
\hline Gaji Karyawan & 4 Orang Rp & $2,565,000.00$ & $\mathrm{Rp}$ & $10,260,000.00$ \\
Administrasi dan Umum & & & & \\
Kertas & 2 Rim Rp & $28,000.00$ & $\mathrm{Rp}$ & $56,000.00$ \\
Tinta Printer & 2 Buah Rp & $55,000.00$ & $\mathrm{Rp}$ & $110,000.00$ \\
Alat Tulis dan Buku & 10 Buah Rp & $4,000.00$ & $\mathrm{Rp}$ & $40,000.00$ \\
Bahan Bakar & 1094 Liter Rp & $7,200.00$ & $\mathrm{Rp}$ & $7,876,800.00$ \\
Perawatan Mesin \& Peralatan & 1 Kali Rp & $500,000.00$ & $\mathrm{Rp}$ & $500,000.00$ \\
Perawatan Kapal & 1 Kali Rp & $5,000,000.00$ & $\mathrm{Rp}$ & $5,000,000.00$ \\
Konsumsi & 4 Orang Rp & $50,000.00$ & $\mathrm{Rp}$ & $200,000.00$ \\
Biaya Sandar/Labuh Pelabuhan & 8 Kali x 515 Ton Rp & 125.00 & $\mathrm{Rp}$ & $515,000.00$ \\
Biaya Muat Pelabuhan & 228 Ton Rp & $18,000.00$ & $\mathrm{Rp}$ & $4,104,000.00$ \\
TOTAL BIAYA & & & $\mathrm{Rp}$ & $24,557,800.00$ \\
\hline
\end{tabular}

Tabel 15. Biaya Operasional SPBN Morodemak

\begin{tabular}{llr}
\hline \multicolumn{1}{c}{ Biaya } & \multicolumn{1}{c}{ Jumlah } \\
\hline Gaji + Honor + Lembur & $\mathrm{Rp}$ & $21,033,000.00$ \\
Administrasi dan Umum & $\mathrm{Rp}$ & $400,000.00$ \\
Asuransi & $\mathrm{Rp}$ & $1,611,450.00$ \\
Listrik, Telp dan PAM & $\mathrm{Rp}$ & $720,000.00$ \\
Perawatan Mesin \& Peralatan & $\mathrm{Rp}$ & $1,300,000.00$ \\
Perawatan Bangunan & $\mathrm{Rp}$ & $3,400,000.00$ \\
Service Kendaraan & & \\
Bahan Bakar Kendaraan & $\mathrm{Rp}$ & $138,000.00$ \\
SPJ dan Promosi & & \\
Konsumsi & $\mathrm{Rp}$ & $300,000.00$ \\
Penyusutan & $\mathrm{Rp}$ & $5,443,938.00$ \\
TOTAL BIAYA & $\mathrm{Rp}$ & $34,346,388.00$ \\
\hline
\end{tabular}

Kesimpulan yang dapat diambil berdasarkan CBA[13], biaya operasional Floating Fuel Station lebih murah dibandingkan dengan SPBN Konvensional dikarenakan Floating Fuel Station tidak memerlukan biaya listrik, telepon, dan PAM tetapi cukup dengan biaya bahan bakar sudah mencakup semuanya.

Dan jumlah total biaya operasional Floating Fuel Station berjumlah Rp.24.557.800,00 dan SPBN Morodemak berjumlah Rp.34.346.388,00. Dilihat dari persentasenya Floating Fuel Station memiliki biaya operasional lebih rendah $28,49 \%$ dibanding dengan biaya operasional SPBN Morodemak Konvensional. 


\subsection{Perbandingan Floating Fuel Station Dengan Propulsi Dan Tanpa Propulsi}

Floating Fuel Station yang dilengkapi dengan sistem propulsi[15] dan tanpa sistem propulsi memiliki kelebihan dan kekurangan masingmasing sesuai dengan kebutuhan dari owner. Floating Fuel Station yang dilengkapi dengan sistem propulsi dan tanpa sistem propulsi memiliki kelebihan dan kekurangan masingmasing sesuai dengan kebutuhan dari owner.

Kelebihan Floating Fuel Station Dengan Sistem Propulsi: 1) Lebih simple dan cepat dalam melayani pendistribusian BBM. 2) Tidak memerlukan biaya sewa untuk kapal tunda. 3) Dapat beroperasi kapanpun dan dimanapun. 4) Tidak bergantung dengan ketersediannya kapal tunda. 5) Lebih praktis dalam mengoperasikannya. Kekurangan Floating Fuel Station Dengan Sistem Propulsi: 1) Mengurangi ruang muat untuk kamar mesin dan perlengkapannya. 2) Memerlukan pembelian bahan bakar untuk perjalanan. 3) Memiliki biaya perawatan yang tinggi. 4) Memiliki biaya tambahan untuk ABK.

Kelebihan Floating Fuel Station Tanpa Sistem Propulsi: 1)Memiliki ruang muat yang lebih banyak. 2) Tidak memerlukan biaya ABK yang banyak. 3) Tidak memerlukan pembelian bahan bakar untuk perjalanan. 4) Memiliki biaya perawatan yang relatif rendah. 5) Konstruksi lebih sederhana. Kekurangan Floating Fuel Station Tanpa Sistem Propulsi: 1)Memerlukan biaya sewa kapal tunda. 2) Pendistribusian BBM sangat bergantung dari ketersediaan kapal tunda. 3) Tidak bisa berlayar kapanpun.

\section{KESIMPULAN}

Didapatkan ukuran utama lambung adalah LOA: 30,0625 m LWL: 28,9690 m LPP: 28,2760 m B: 11,5 m H: 2,5 m T: 1,8 m Displacement: 515,1 Ton Cb: 0,8737 LCB dari MS: $-0,061$. DWT: 257,592 Ton dan LWT: 257,508 Ton.

Didapatkan total HP yang dibutuhkan sebesar 255,5 HP, dengan nilai hambatan total sebesar 29,6 kN. Hasil analisa stabilitas Floating Fuel Station di setiap kondisi memenuhi semua kriteria IMO MSC.267(85) Code on intacts stability Part $B$ For Pontoons. Hasil Analisa Seakeeping berdasarkan kriteria yang ditetapkan oleh (Tello, 2009) untuk sudut maksimum roll adalah 6 derajat dan sudut maksimum untuk pitch adalah 3 derajat, untuk standar laut normal perairan Pantai Utara Jawa dengan gelombang maksimal $2 \mathrm{~m}$, Floating Fuel Station memenuhi kriteria olah gerak yang ditentukan oleh Tello 2009.
Dari hasil analisa CBA, jumlah total biaya operasional Floating Fuel Station berjumlah Rp.24.557.800,00 dan SPBN Morodemak berjumlah Rp.34.346.388,00. Dilihat dari persentasenya Floating Fuel Station memiliki biaya operasional lebih rendah $28,49 \%$ dibanding dengan biaya operasional SPBN Morodemak Konvensional. Floating Fuel Station yang dilengkapi dengan sistem propulsi dan tanpa sistem propulsi memiliki kelebihan dan kekurangan masing-masing sesuai dengan kebutuhan dari owner.

Floating Fuel Station diharapkan menjadi solusi bagi pemerintah untuk mengatasi masalah pendistribusian BBM di daerah pesisir terutama pesisir pantai Morodemak Kabupaten Demak yang dimana daerah tersebut sulit dijangkau oleh jalur darat.

\section{UCAPAN TERIMA KASIH}

Ucapan terima kasih penulis sampaikan kepada Pimpinan Dinas Kelautan dan Perikanan Kabupaten Demak, PPP Morodemak, PT. Anwusa Demak, PT. Pertamina Persero, PT. AKR Corporindo dan Masyarakat nelayan Pantai Morodemak yang sudah membantu memberikan data untuk keperluan penelitian tugas akhir ini.

\section{DAFTAR PUSTAKA}

[1] S. M. Darmawan, "Indonesia Sebagai Negara Maritim," Indones. Sebagai Negara Marit., 2012.

[2] S. Martin, "Pola Distribusi BBM Di Indonesia Paling Kompleks Sedunia," Pola Distribusi BBM Di Indonesia Paling Kompleks Sedunia, 2014. [Online]. Available:

http://industri.bisnis.com/read/20140415/4 4/219762/pola-distribusi-bbm-diindonesia-paling-kompleks-sedunia.

PT. Pertamina, "KEBIJAKAN PEMBANGUNAN SPBN/SPDN DALAM MEMENUHI KEBUTUHAN BBM BAGI NELAYAN," Jakarta, 2016.

[4] E. S. M. Hadi Imam Pujo; Santosa, Ari Wibawa Budi, "PEMBERDAYAAN KELOMPOK NELAYAN TANGKAP TRADISIONAL DI KAWASAN PESISIR PANTAI MORO DEMAK DALAM UAPAYA PENINGKATAN PRODUKSI DAN PENGHEMATAN BBM," Kapal, no. Vol 12, No 3 (2015): Oktober, pp. 151-157, 2015.

[5] G. Rindo, "Design Spiral dan perancangan kapal," 2011. [Online]. Available: 
http://goodrindo.blogspot.co.id/2011/10/de sign-spiral-dan-perancangan-kapal.html.

[6] Dinas Kelautan dan Perikanan Kabupaten Demak, "Surat Rekomendasi Dan Verifikasi Kapal Nelayan,” Demak, 2017.

[7] J. J. Made I Gusti, Teori Bangunan Kapal I dan II. Jakarta: Soetrisno Bsc, 1982.

[8] BMKG, "Prakiraan Tinggi Gelombang," 2017. [Online]. Available: http://petamaritim.bmkg.go.id/static/.

[9] IMO, Code on intacts stability Part B For Pontoons. .

[10] P. Manik, "ANALISA GERAKAN SEAKEEPING KAPAL PADA GELOMBANG REGULER," KAPAL, no. Vol 4, No 1 (2007): JURNAL ILMU PENGETAHUAN \& TEKNOLOGI KELAUTAN, pp. 1-10, 2007.

[11] M. Tello, S. Ribeiro E Silva, and C. Guedes Soares, "Seakeeping performance of fishing vessels in irregular waves," Ocean Eng., vol. 38, no. 5-6, pp. 763-773, 2011.

[12] M. Iqbal and G. Rindo, "OPTIMASI BENTUK DEMIHULL KAPAL KATAMARAN UNTUK MENINGKATKAN KUALITAS SEAKEEPING," KAPAL, vol. 12, pp. 1924, 2015.

[13] Muslihati, "ANALISIS BIAYA OPERASIONAL KAPAL PADA BERBAGAI LOAD FAKTOR ANGKUTAN PERINTIS," ILTEK, vol. 7, no. Biaya Operasional Kapal, 2012.

[14] WikiHow, "Cara Melakukan Analisis Biaya," 2017. [Online]. Available: https://id.wikihow.com/MelakukanAnalisis-Biaya.

[15] N. B. A. Prayoga Wasis Dwi, "Desain Self-Propelled Oil Barge (SPOB) Untuk Distribusi Crude Oil di Kabupaten Sorong, Papua Barat," J. Tek. ITS, no. Vol 5, No 1, 2016. 